\title{
Origin and distribution of the coronary arteries of boars
}

\section{Origem e distribuição das artérias coronárias de javalis}

\author{
Tânia Ribeiro Junqueira BORGES ${ }^{1,2}$; Lucas de Assis RIBEIRO²; Fabiano Braz ROMÃO²; \\ Henrique Inhauser Riceti MAGALHÃES ${ }^{2,3}$; Marcos Martins LUZ ${ }^{2}$; Jeferson Borges BARCELOS ${ }^{2,4}$; \\ Lázaro Antônio dos SANTOS ${ }^{1,2}$; Frederico Ozanam Carneiro e SILVA ${ }^{1,2}$ \\ ${ }^{1}$ Universidade Federal de Uberlândia, Campus Umuarama, Faculdade de Medicina \\ Veterinária, Laboratório de Anatomia Animal, Uberlândia - MG, Brazil \\ ${ }^{2}$ Centro Universitário de Patos de Minas, Faculdade de Medicina Veterinária, Grupo de \\ Pesquisa em Anatomia Comparativa, Patos de Minas - MG, Brazil \\ ${ }^{3}$ Universidade de São Paulo, Faculdade de Medicina Veterinária e Zootecnia, \\ Departamento de Cirurgia, Setor de Anatomia, São Paulo - SP, Brazil \\ ${ }^{4}$ Fundação Presidente Antônio Carlos, Faculdade de Medicina Veterinária, Uberlândia - MG, Brazil
}

\begin{abstract}
The heart of a domestic swine is similar to that of a human regarding anatomy, blood perfusion, and distribution of nurturing arteries. In addition to the similarities, its low cost compared with other species is also one of the reasons these animals have been increasingly used in medical schools and in clinical, surgical, and pharmacological studies. Therefore, we aimed to identify the origin and distribution of the right and left coronary arteries of boars, emphasizing the configuration and macroscopic representativity of their branches while characterizing a possible dominance concerning the type of circulation and the potential use of this animal as an experimental model, hence boars are the ancestors of the domestic pigs. The left coronary artery has bifurcated into paraconal interventricular branch and circumflex branch; or it has trifurcated into paraconal interventricular branch, the oblique branch, and into the left circumflex branch. The right coronary artery has originated the marginal branches to the right ventricle and the right circumflex branch, which has branched out in the subsinuous interventricular branch. Anastomoses have stood out among the paraconal and subsinuous interventricular branches - where a right dominant coronary artery occurred and between the right and left circumflex branches. We concluded that the morphology and the distribution of the coronary arteries of boars resemble those of a human and, thus, our results are useful for the conception of experimental hemodynamics and possible use as process models.
\end{abstract}

Keywords: Angiology. Blood flow. Crux cordis. Morphology. Suidae.

\section{Resumo}

O coração dos suínos domésticos apresenta semelhanças ao dos humanos mediante a anatomia, perfusão sanguínea e configuração da distribuição de suas artérias nutridoras. Tendo um menor custo para sua aquisição quando comparado a outras espécies, e dada sua similaridade apresentada, o uso desses animais nas escolas de medicina, em estudos clínicos, cirúrgicos e farmacológicos tem aumentado. Portanto, objetivou-se identificar a origem e distribuição das artérias coronárias direita e esquerda de javalis com ênfase na configuração e representatividade macroscópica dos ramos derivados das mesmas, caracterizando uma possível dominância quanto ao tipo de circulação e o potencial uso deste suídeo como modelo experimental, visto que são considerados ancestrais dos suínos domésticos. A artéria coronária esquerda bifurcou-se e deu origem aos ramos interventricular paraconal e circunflexo esquerdo, ou trifurcouse nos ramos interventricular paraconal, oblíquo e circunflexo esquerdo. Já a artéria coronária direita deu origem aos ramos marginal para o ventrículo direito e circunflexo direito que, por sua vez, ramificou-se no ramo interventricular subsinuoso. Foram evidenciadas anastomoses entre os ramos interventriculares paraconal e subsinuoso, e entre os ramos circunflexos direito e esquerdo e, conforme tal origem do ramo interventricular subsinuoso, a forma de dominância coronariana foi predominantemente direita. Conclui-se que a morfologia e distribuição das artérias coronárias de javalis se assemelham à do homem e, desse modo, nossos resultados são úteis para sua concepção da hemodinâmica experimental, e possível utilização como modelos processuais.

Palavras-chave: Angiologia. Circulação. Crux cordis. Morfologia. Suidae. 
Correspondence to:

Tânia Ribeiro Junqueira Borges

Universidade Federal de Uberlândia, Faculdade de Medicina

Veterinária, Laboratório de Anatomia Animal

Rua Ceará, s/n, Bloco 2D - Umuarama

CEP 38400-902, Uberlândia, MG, Brazil

e-mail: taniarborges@yahoo.com.br

Received: 25/08/2018

Approved: 26/11/2018

\section{Introduction}

Boars are mammals originated from North Africa and Southwest Asia (BOSMA et al., 1996). Considered the ancestor of the domestic pigs (CROSBY, 1993), boars belong to the Suidae family, which is represented by five genera, including the Babyrousa and the Sus (BOSMA et al., 1996). Within the genus Sus, five living species are listed, the Sus scrofa being one of them (NOWAK, 1999).

The heart of a domestic swine is similar to that of a Human, not only in terms of size, anatomy, distribution of blood perfusion, and cardiovascular physiology (HUGHES, 1986), but also in terms of the distribution of arteries (GÓMEZ; BALLESTEROS, 2013, 2014, 2015).

The basic research carried out with animals indicate that these physiological, anatomical, and organic similarities expand the applicability of the conclusions obtained (SCHANAIDER; SILVA, 2004).

Based on the above, we aimed to identify the origin and distribution of the coronary arteries of boars, emphasizing the configuration and macroscopic representativity of their branches and characterizing a possible dominance regarding the type of circulation and the potential use of this animal as an experimental model.

\section{Materials and Methods}

The project has been approved by the Animal Ethics Committee of the Federal University of Uberlândia, under protocol no. 103/13. Fifty hearts of boars with a mean age of eight months, average body weight of 42 kilos, of both sexes (25 males and 25 females), with no apparent heart disease and from the Temra commercial nursery (SP) were used. The hearts were collected immediately after the humane slaughter of the animals, which was performed in compliance with the routine and standard procedures adopted by the nursery. Soon after that, the material was forwarded to the Laboratory of Animal Anatomy of the Federal
University of Uberlândia, where all of the subsequent phases of preparation were conducted.

The hearts were cut with two cross sections at the aorta and the pulmonary trunk arteries, close to their respective valves. Once the lumen of the ascending aorta was visible, the right and left coronary ostia were identified and cannulated for the injection of latex aqueous solution (polyvinyl acetate, $\left(\mathrm{C}_{4} \mathrm{H}_{6} \mathrm{O}_{2}\right)_{\mathrm{n}}$, Artecola ${ }^{\circledR}$, Brazil) and red stained (water base dye, Suvinil ${ }^{\bullet}$ Tintas e Pigmentos, Brazil). Subsequently, the hearts were allocated in bowls and immersed into $10 \%$ formaldehyde (methanol 0.8-3\% $\left(\mathrm{CH}_{2} \mathrm{O}\right)$, $\mathrm{Chemco}^{\circ}$ - formaldehyde solution GEIII, Brazil), where they remained for 15 days. Dissections began only after that period elapsed.

The dissection of both right and left coronary arteries started from the right and left coronary ostia, which were isolated from the fatty and connective tissues for better visualization of the distribution of the myocardial fibers.

The determination of the type of coronary circulation in boars was based on the concept suggested by Schlesinger (1940), which consists in analyzing the irrigation on the atrial face of the hearts, especially regarding the arterial supply of the crux cordis region (an area resulting from the intersection between the subsinuous and coronary interventricular grooves and the interatrial sulcus). For such characterization, according to the author mentioned, the coronary circulation may be characterized as a balanced type or as left or right dominant types. The right dominance type occurs when the circumflex branch of the right coronary artery crosses the crux cordis and presses one or more branches to the left ventricle. When the circumflex branch of the left coronary artery presses the subsinuous interventricular branch and sends off at least one branch to the right ventricle, a left dominance type occurs. Finally, once both arteries reach the crux cordis and the subsinuous interventricular branch is derived from the right coronary artery, the coronary dominance is characterized as balanced, even though there is no distribution to the left ventricle.

The anatomical nomenclature used to designate the structures identified is in accordance with the International Committee on Veterinary Gross Anatomical Nomenclature (2017), while, in references to studies concerning humans, the terms used by the authors were maintained. For a statistical description of the coronary arteries and their branches, only a descriptive analysis by absolute values and simple percentage was consulted. 


\section{Results}

In boars, the left coronary artery stretched between the pulmonary trunk artery and the left auricle towards the auricular face, where it split into two $(n=39 / 78 \%)$ or three branches ( $\mathrm{n}=11 / 22 \%)$ (Figure 1). The bifurcation of the left coronary artery was observed in the hearts of 19 males (76\%) and 20 females (80\%), resulting in the paraconal interventricular branch and in the circumflex branch of the left coronary artery. The trifurcation of left coronary artery was observed in the hearts of six males (24\%) and five females (20\%), and resulted in the paraconal interventricular branch, in the oblique branch of the left coronary artery, and in the circumflex branch of the left coronary artery.

The paraconal interventricular branch of the left coronary artery stretched along the paraconal interventricular groove towards the apex of the heart and provided an average of 10.92 branches for the right ventricle and 10.82 branches for the left ventricle. In $100 \%$ of the samples, the first branch assigned to the right ventricle was identified as the branch of the paraconal interventricular branch to the conus arteriosus (Figure 1). Anastomoses between the apical branches of the paraconal interventricular branch of the left coronary artery and the apical branches of the subsinuous interventricular branch of the right coronary artery have been observed in 19 hearts (10 males and nine females) (Figure 2).

The oblique branch of the left coronary artery, resulting from its trifurcation, was originated in the angle between the paraconal interventricular branch and the circumflex branch of the left coronary artery, maintaining the condition of oblique architecture in a dorsal-ventral and caudal organization while skewing towards the caudal border and the cardiac apex (Figure 1B).

In all of the samples, the circumflex branch of the left coronary artery ranged from the coronary groove to the caudal border of the heart while reaching its atrial face and, along its course, it produced several branches to the left atrium and auricle (Figure 1). The artery mentioned also provided an average of 9.20 branches for the left ventricle.

The marginal branch of the left coronary artery came from the circumflex branch of the left coronary artery (Figure 1A) in the hearts of 23 males (92\%) and 22 females $(88 \%)$, and it ranged from the caudal border of the organ along the left ventricle towards the cardiac apex.

Table 1 shows the final distributions of the arterial branches derived from the left coronary artery of the hearts of boars.
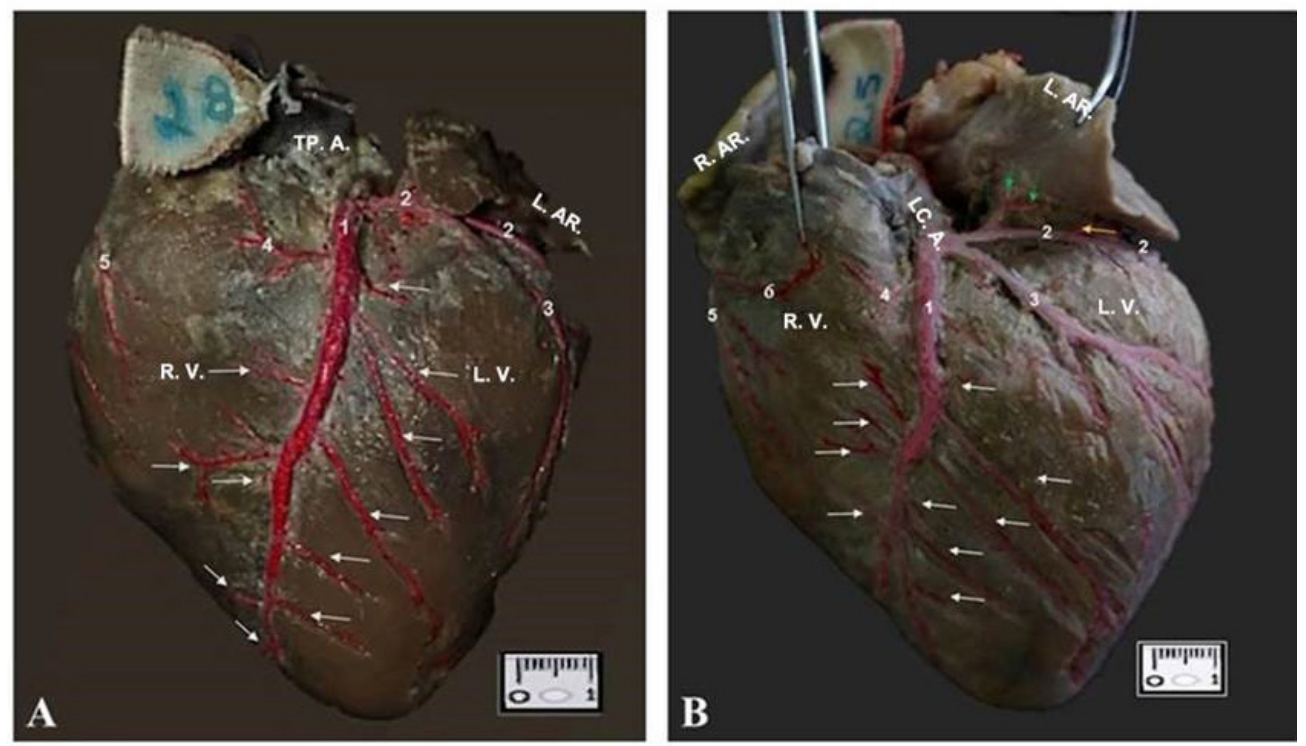

Figure 1 - (A) Macro photography of the auricular face of the heart of Sus scrofa, highlighting the bifurcation of the left coronary artery; pulmonary trunk artery (TP.A.); left auricle (L.AR.); 1 paraconal interventricular branch; 2 circumflex branch of the left coronary artery; 3 branch of the left paraconal interventricular branch to the conus arteriosus; 4 left marginal branch; 5 left branch of the right marginal branch; right (R.V.) and left (L.V.) ventricles; septal branches of the paraconal interventricular branch (white arrow). (B) Macro photography of the auricular face of the heart of Sus scrofa, highlighting the trifurcation of the left coronary artery; 1 paraconal interventricular branch of the left coronary artery; 2 circumflex branch of the left coronary artery; 3 oblique branch of the left coronary artery; 4 branch of the left paraconal interventricular branch to the conus arteriosus; 5 left branch of the right marginal branch; 6 branch of the right coronary artery to the conus arteriosus; septal branches of the paraconal interventricular branch (white arrow); branch of the left circumflex branch to the right atrium (yellow arrow); branch of the left circumflex branch to the left auricle (green arrow); left coronary artery (LC.A.); right (R.V.) and left (L.V.) ventricles; right (R.AR.) and left (L.AR.) auricles 

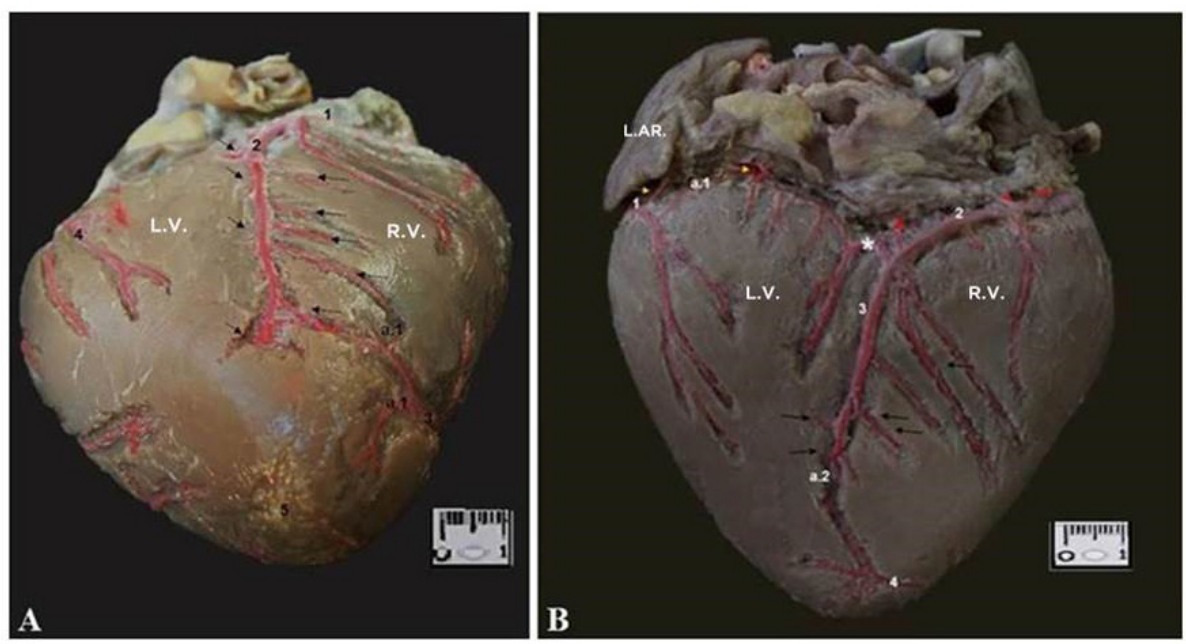

Figure 2 - (A) Macro photography from a ventricular-auricular perspective of the heart of Sus scrofa, setting off the anastomosis between the paraconal interventricular branch of the left coronary artery and the subsinuous interventricular branch of the right coronary artery at the level of the ventral third of the cardiac atrial face (a.1); 1 circumflex branch of the right coronary artery; 2 subsinuous interventricular branch of the right coronary artery; 3 paraconal interventricular branch of the left coronary artery; 4 left marginal branch; 5 cardiac apex; septal branches of the subsinuous interventricular branch (black arrows); right (R.V.) and left (L.V.) ventricles. (B) Macro photography of the atrial face of a heart of Sus scrofa, setting off the circulation with right-dominant type and anastomosis between the circumflex branches of the right and left coronary artery at the level of the crux cordis. 1 circumflex branch of the left coronary artery; crux cordis $\left.{ }^{*}\right)$; 2 circumflex branch of the right coronary artery; 3 subsinuous interventricular branch of the right coronary artery; 4 paraconal interventricular branch of the left coronary artery; anastomosis between the circumflex branches of the right and left coronary arteries (a.1); anastomosis between the paraconal interventricular branches of the left coronary artery and the subsinuous of the right coronary artery (a.2); septal branches of the subsinuous interventricular branch (black arrows); atrial branches of the circumflex branch of the right coronary artery (yellow arrows); atrial branches of the circumflex branch of the left coronary artery (red arrows); right (R.V.) and left (L.V.) ventricles; left auricle (L.AR.)

Table 1 - Final distribution of the arterial branches derived from the left coronary artery in the hearts of Sus scrofa - total, and in accordance with sex - Uberlândia, Brazil - 2018

\begin{tabular}{|c|c|c|c|c|c|c|}
\hline & \multicolumn{2}{|c|}{ Males } & \multicolumn{2}{|c|}{ Females } & \multicolumn{2}{|c|}{ Total samples } \\
\hline & $\mathbf{n}^{\circ}$ & $\%$ & $\mathbf{n}^{\circ}$ & $\%$ & $\mathbf{n}^{\circ}$ & $\%$ \\
\hline & \multicolumn{6}{|c|}{ Paraconal interventricular branch } \\
\hline Cardiac apex & 02 & 08 & 04 & 16 & 06 & 12 \\
\hline Ventral third of the atrial face (R.V. and L.V.) & 17 & 68 & 16 & 64 & 33 & 66 \\
\hline Atrial face (SS.I.) & 06 & 24 & 05 & 20 & 11 & 22 \\
\hline \multirow[t]{2}{*}{ Total } & 25 & 100 & 25 & 100 & 50 & 100 \\
\hline & \multicolumn{6}{|c|}{ Oblique branch } \\
\hline Mid-third (L.V., A.F) & 03 & 50 & 02 & 40 & 05 & 45.45 \\
\hline Ventral third (L.V., A.F) & 02 & 33.33 & 02 & 40 & 04 & 36.36 \\
\hline Mid-third (L.V., AT.F) & 01 & 16.67 & 01 & 20 & 02 & 18.19 \\
\hline \multirow[t]{2}{*}{ Total } & 06 & 100 & 05 & 100 & 11 & 100 \\
\hline & \multicolumn{6}{|c|}{ Circumflex branch } \\
\hline Before crux cordis & 23 & 92 & 24 & 96 & 47 & 94 \\
\hline Reaching the crux cordis & 01 & 04 & 01 & 04 & 02 & 04 \\
\hline Reaching the S.IS. & 01 & 04 & - & - & 01 & 02 \\
\hline \multirow[t]{2}{*}{ Total } & 25 & 100 & 25 & 100 & 50 & 100 \\
\hline & \multicolumn{6}{|c|}{ Marginal branch } \\
\hline Dorsal third (L.V) & 04 & 17.39 & 04 & 18.18 & 08 & 17.77 \\
\hline Mid-third (L.V.) & 08 & 34.78 & 07 & 31.82 & 15 & 33.34 \\
\hline Ventral third (L.V., A.F.) & 08 & 34.78 & 08 & 36.36 & 16 & 35.56 \\
\hline Ventral third (L.V., AT.F.) & 03 & 13.05 & 03 & 13.64 & 06 & 13.33 \\
\hline Total & 23 & 100 & 22 & 100 & 45 & 100 \\
\hline
\end{tabular}

R. V. = Right ventricle; L. V. = Left ventricle; SS. I. = Subsinuous interventricular groove; A. F. = Auricular face; AT. F. = Atrial face 
The right coronary artery stretched between the pulmonary trunk artery and the right auricle as far as the coronary groove to ramify throughout the auricular and atrial faces after the formation of the marginal branches of the right coronary artery, the circumflex branch of the right coronary artery and the subsinuous interventricular branch of the right coronary artery. Once on the atrial face, the artery produced to the right ventricle in $84 \%$ of the hearts of both sexes, the branch of the coronary artery to the conus arteriosus. The short marginal branch of the right coronary artery has been identified in all of the hearts of boars (Figure 3).

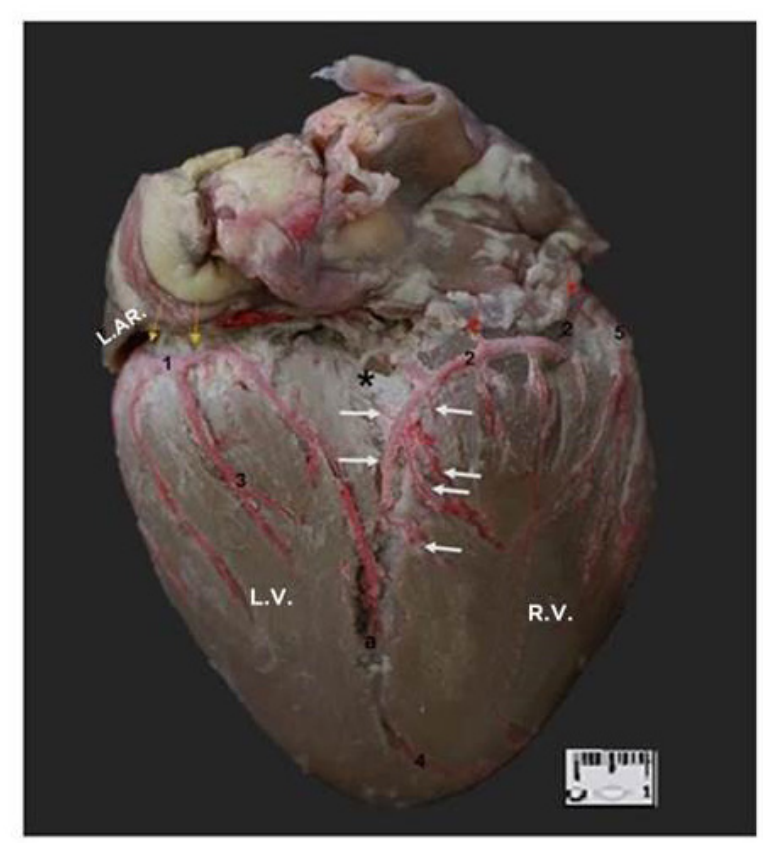

Figure 3 - Macro photography of the atrial face of a heart of Sus scrofa. Left auricle (L.AR.); 1 left circumflex branch; crux cordis $\left.{ }^{*}\right)$; 2 right circumflex branch; 3 left marginal branch; subsinuous interventricular groove (a); 4 paraconal interventricular branch; septal branches of the subsinuous interventricular branch (white arrows); atrial branches of the left circumflex branch (yellow arrows); atrial branches of the right circumflex branch (red arrows); right (R.V.) and left (L.V.) ventricles

In all of the samples of boars, the circumflex branch of the right coronary artery stretched along the coronary groove, where it produced an average of 8.94 branches to the right ventricle and reached the subsinuous interventricular groove in $100 \%$ of the cases, becoming the subsinuous interventricular branch of the right coronary artery (Figure 2A). Thus, in conformity with the methodology proposed, the coronary denomination in the boars has been characterized as that of the right-side.

The circumflex branch of the right coronary artery reached the crux cordis in all of the samples, in 15 males
(60\%) and 18 females (72\%), while it traversed the region to ramify throughout the dorsal third of the left ventricle, in its atrial face, producing an average of two branches. It is noteworthy that, in two male hearts (8\%) and in one female heart (4\%), an anastomosis was identified between the circumflex branches coming from the right and left coronary arteries (Figure 2B).

The subsinuous interventricular branch of the right coronary artery ranged from the corresponding groove towards the cardiac apex (Figure 2B), ramifying throughout three different regions: ventral, mid- and dorsal thirds. In $2 \%$ of the cases, the subsinuous interventricular groove has its dorsal third occupied by the circumflex branch of the right coronary artery and, in its mid- and distal thirds, by the branch coming from the circumflex branch of the left coronary artery. When the subsinuous interventricular branch of the right coronary artery occupied the entire subsinuous interventricular groove, it produced an average of 6.20 and 4.78 septal branches to the right and left ventricles, respectively.

Table 2 shows the final distributions of the arterial branches derived from the right coronary artery of the hearts of boars.

Table 2 - Final distribution of the arterial branches derived from the right coronary artery in the hearts of Sus scrofa - total, and in accordance with sex - Uberlândia, Brazil - 2018

\begin{tabular}{lcccccc}
\hline & Males & Females & \multicolumn{2}{c}{$\begin{array}{c}\text { Total } \\
\text { samples }\end{array}$} \\
\hline & $\mathbf{n}^{\circ}$ & $\%$ & $\mathbf{n}^{\circ}$ & $\%$ & $\mathbf{n}^{\circ}$ & $\%$ \\
\hline Dorsal third (R.V.) & 08 & 32 & 05 & 20 & 13 & 26 \\
Mid-third (R.V.) & 12 & 48 & 13 & 52 & 25 & 50 \\
Mid-third (R.V., AT.F.) & 05 & 20 & 07 & 28 & 12 & 24 \\
Total & 25 & 100 & 25 & 100 & 50 & 100 \\
\hline & Subsinuous interventricular branch \\
\hline Mid-third (SS.I.) & 12 & 48 & 07 & 28 & 19 & 38 \\
Ventral third (SS.I.) & 03 & 12 & 10 & 40 & 13 & 26 \\
Cardiac apex & 10 & 40 & 04 & 16 & 14 & 28 \\
Traverses the cardiac & - & - & 04 & 16 & 04 & 08 \\
apex (R.V., A.F.) & \multicolumn{7}{c}{. } & & & & & \\
Total & 25 & 100 & 25 & 100 & 50 & 100 \\
\hline
\end{tabular}

R.V. = Right ventricle; AT.F. $=$ Atrial face; SS.I. $=$ Subsinuous interventricular groove; A.F. = Auricular face

\section{Discussion}

Studies on the distribution of the coronary arteries of boars were not found in the literature, so it was not possible to establish comparisons. All of the hearts of such species presented one right coronary artery and one left coronary 
artery from the respective coronary ostia of the ascending aorta, just as described by König and Liebich (2011) for domestic animals, Gómez and Ballesteros $(2013,2014)$ for swine, and by Netter (2008) for humans.

The results observed regarding the division of the left coronary artery show that $78 \%$ of cases of bifurcation in boars are similar to the $80 \%$ and $79 \%$ observed by Moura Junior et al. (2008) and Gómez and Ballesteros (2014) in 30 and 158 swine, respectively. Concerning the trifurcation of the left coronary artery, $22 \%$ of the cases recorded in this study were respectively consistent with the $20 \%$ and $21 \%$ observed by Moura Junior et al. (2008) and Gómez and Ballesteros (2014). Lima Júnior and Prates (1994), on the other hand, report the occurrence, in humans, of trifurcation in $38.70 \%$ of the 50 samples studied - a figure higher than the $8 \%$ mentioned by Abuchaim et al. (2009) in 25 hearts. Findings such as these set off the broad variation regarding the distribution of those arteries, even when the same methodology of assessment is consulted.

The paraconal interventricular branch in boars ranged from the paraconal interventricular groove to the cardiac apex, just as recorded in swine (MOURA JUNIOR et al., 2008; GÓMEZ; BALLESTEROS, 2014) and goats (MOURA JUNIOR et al., 2009). The left branch to the conus arteriosus was the first branch emerging to the right of the paraconal interventricular branch for the right ventricle in all of the samples, just as described in swine (SAHNI et al., 2008) and in humans (LIMA JÚNIOR et al., 1993). In boars, the paraconal interventricular branch traversed the cardiac apex and reached the atrial face in $66 \%$ of the samples, which shows the importance of that arterial branch, given the vast area irrigated by it; its occlusion may provoke widely extended infarctions.

The oblique branch of the left coronary artery, originated in the angle between the paraconal interventricular branch and the left circumflex branch, takes on different synonymies in the animals when the trifurcation of the left coronary artery is present. In swine, the oblique branch is described as the diagonal branch (MOURA JUNIOR et al., 2008) and as the diagonal artery (GÓMEZ; BALLESTEROS, 2014); in goats, it is described as the angular branch (MOURA JUNIOR et al., 2009); and still, it has been observed as the left marginal branch in rabbits (CORREIA-OLIVEIRA et al., 2014). For boars, the arterial denomination adopted is based on the oblique distribution in a dorsal-ventral and caudal organization.
The oblique branch of the left coronary artery in the $S$. scrofa was similar to other results observed in swine, as the $20 \%$ (diagonal branch) reported by Gómez and Ballesteros (2014). In humans, that branch has been described as the diagonal branch by Banchi (1904) in 38.7\% of the hearts studied, and it provides supplementary irrigation in the cases of obliteration of the collateral branches of the anterior descending artery (PAULA, 1972).

The left circumflex branch, in all of the hearts of boars, had a path similar to the one observed in swine (GÓMEZ; BALLESTEROS, 2014), and it reached the crux cordis in $94 \%$ of the cases, while, in humans, the artery would not surpass the crux cordis in $72 \%$ of the samples (LIMA JÚNIOR et al., 1993).

In $84 \%$ of the samples of boars, the right branch to the conus arteriosus was the first to emerge on the left of the right coronary artery, and, in swine, Sahni et al. (2008) found that branch in $100 \%$ of their samples. As well as in this study, Abuchaim et al. (2009) observed, in humans, the branch of the conus arteriosus with its origin in the right coronary artery.

Studies on coronary arteries in humans describe that the right coronary artery occupies the coronary groove, produces branches to the left ventricle and atrium, and correlates their finalization about reaching, or even surpassing, the crux cordis (VILALLONGA, 2003; ABUCHAIM et al., 2009), enabling thus the correlation of that segment to the right circumflex branch in the Sus scrofa. In the literature consulted regarding ruminants, such as bovines (CORREIA-OLIVEIRA et al., 2013) and goats (MOURA JUNIOR et al., 2009), we verified that the right coronary artery has traits that are similar to those aforementioned; however, it is short and does not reach the crux cordis, or the subsinuous interventricular groove.

The subsinuous interventricular branch in boars was the continuation of the circumflex branch of the right coronary artery in $100 \%$ of the subjects, close to the results observed in swine, in 96.7\% (VIEIRA et al., 2008) and in $100 \%$ of the samples (MOURA JUNIOR et al., 2008; GÓMEZ; BALLESTEROS, 2013). Nevertheless, in goats (MOURA JUNIOR et al., 2009) and in half-breed bovines (CORREIA-OLIVEIRA et al., 2013), this branch had its origin through the left circumflex branch. In humans, the posterior interventricular branch was the branch of the right coronary artery in $72 \%$ of the 25 hearts assessed by Abuchaim et al. (2009).

According to Kyriakidis et al. (1995), the development of anastomoses in humans is correlated to the chronic 
ischemia; and it has been reported that they occur mainly between the septal branches, the branch of the conus arteriosus, and the atrial branches; however, in boars, the anastomoses were recorded only between the apical branches of the paraconal and subsinuous interventricular branches and between the circumflex branches of the right and left coronary arteries.

In accordance with the concept of dominance proposed by Schlesinger (1940), regarding the arterial supply of the crux cordis, the standard of the right dominant type was observed in the entirety of the samples of boars of both sexes. This way, $100 \%$ of the samples of swine evaluated by Sahni et al. (2008) and Moura Junior et al. (2008) presented right coronary dominance. Still regarding swine, apart from the presence of the right dominant type in $78 \%$ of the 75 hearts studied, Weaver et al. (1986) described that $17 \%$ of those had circulation of the balanced type, and that $5 \%$ had left dominant circulation. Unlike the results presented in the S. scrofa, the left dominant circulation prevailed in half-breed bovines (CORREIA-OLIVEIRA et al., 2013).

Lima Júnior et al. (1993) reveal a prevalence of the right dominant type in humans, being present in $72 \%$ of the hearts analyzed, $16 \%$ of left dominant type and $12 \%$ of balanced dominance.

Vasko et al. (1961) claims that the anatomical dominance does not correspond, entirely, to the functional dominance, hence the perfusion dominance, which reflects this functional prevalence of the coronary arteries and reveals an inversion of values, with $69 \%$ of the left dominant type.
In accord with the considerations of the aforementioned authors, Vilallonga (2003) recorded that the use of the terms right or left coronary "predominance" or "dominance", as proposed by Schlesinger (1940), could provide a mistaken idea that the dominant artery would irrigate the major part of the myocardium when, in fact, its major part has always been irrigated by the left coronary artery.

\section{Conclusion}

The right and left coronary arteries emerged from the corresponding coronary ostia of the ascending aorta. The left coronary artery bifurcated and originated the left circumflex and paraconal interventricular branches; or it has trifurcated into the left circumflex, oblique, and paraconal interventricular branches. The right coronary artery originated the marginal branches to the right ventricle and right circumflex, which followed as the subsinuous interventricular branch in the groove of the same name. The dominance mode of the coronary circulation has been predominantly right sided.

Boars and humans, despite belonging to different taxons, showed characteristics of homoplasy regarding coronaryan distribution and, thus, our results are useful for the conception of the experimental hemodynamics and their possible use as process models.

\section{Conflict of Interest}

The author(s) declare(s) that there is no conflict of interest regarding the publication of this article.

\section{References}

ABUCHAIM, D. C. S.; SPERA, C. A.; FARACO, D. L.; RIBAS FILHO, J. M.; MALAFAIA, O. Coronary dominance patterns in the human heart investigated by corrosion casting. Brazilian Journal of Cardiovascular Surgery, v. 24, n. 4, p. 514-518, 2009. doi: 10.1590/S0102-76382009000500013.

BANCHI, A. Morfologia delle arteriae coronariae cordis. Archivio Italiano di Anatomia e di Embriologia, v. 3, p. $87-164,1904$.

BOSMA, A. A.; DE HAAN, N. A.; MELlinK, C. H. M.; YERLE, M.; ZIJLSTRA, C. Chromosome homology between the domestic pig and the babirusa (family Suidae) elucidated with the use of porcine painting probes. Cytogenetics and Cell Genetics, v. 75, n. 1, p. 32-35, 1996. doi: 10.1159/000134452.

CORREIA-OLIVEIRA, M.; HERNANDEZ, J. M. F.; ABIDU-FIGUEIREDO, M. Morfometria cardíaca e distribuição das artérias coronárias em bovinos mestiços. Biotemas, v. 26, n. 2, p. 199-207, 2013. doi: 10.5007/2175-7925.2013v26n2p199.

CORREIA-OLIVEIRA, M.; OLIVEIRA, I. M. S.; ROZA, M. S.; ABIDU-FIGUEIREDO, M. Morfometria cardíaca e distribuição das artérias coronárias em coelhos Nova Zelândia (Oryctolagus cunniculus). Revista Brasileira de Medicina Veterinária, v. 36, n. 2, p. 159-166, 2014. 
CROSBY, A. W. Imperialismo ecológico: a expansão biológica da Europa 900-1900. São Paulo: Companhia das Letras, 1993. 319 p.

GÓMEZ, F. A.; BALLESTEROS, L. E. Anatomic study of the right coronary artery in pigs: feature review in comparison with the human artery. International Journal of Morphology, v. 31, n. 4, p. 1289-1296, 2013. doi: 10.4067/S0717-95022013000400023.

GÓMEZ, F. A.; BALLESTEROS, L. E. Morphologic expression of the left coronary artery in pigs: an approach in relation to human heart. Revista Brasileira de Cirurgia Cardiovascular, v. 29, n. 2, p. 214-220, 2014. doi: 10.5935/1678-9741.20140027.

GÓMEZ, F. A.; BALLESTEROS, L. E. Evaluation of coronary dominance in pigs: a comparative study with findings in human hearts. Arquivo Brasileiro de Medicina Veterinária e Zootecnia, v. 67, n. 3, p. 783789, 2015. doi: 10.1590/1678-4162-6637.

HUGHES, H. C. Swine in cardiovascular research. Laboratory Animal Science, v. 36, n. 4, p. 348-350, 1986.

INTERNATIONAL COMMITTEE ON VETERINARY GROSS ANATOMICAL NOMENCLATURE. Nomina anatomica veterinaria. 6. ed. Hanover: ICVGAN Editorial Committee, 2017. 178 p.

KÖNIG, H. E.; LIEBICH, H. G. Anatomia dos animais domésticos: texto e atlas colorido. 4. ed. Porto Alegre: Artmed, 2011. 824 p.

KYRIAKIDIS， M.; PETROPOULAKIS， P.; ANDROULAKIS, A.; ANTONOPOUlOS, A.; A postolopoulos, T.; BARBETSEAS, J.; VYSSOULIS, G.; TOUTOUZAS, P. Sex differences in the anatomy of coronary artery disease. Journal of Clinical Epidemiology, v. 48, n. 6, p. 723-730, 1995. doi: 10.1016/0895-4356(94)00194-U.

LIMA JÚNIOR, R.; CABRAL, R. H.; PRATES, N. E. V. B. Tipos de circulação e predominância das artérias coronárias em corações de brasileiros. Revista Brasileira de Cirurgia Cardiovascular, v. 8, n. 1, p. 9-19, 1993. doi: 10.1590/S0102-76381993000100002.
LIMA JÚNIOR, R.; PRATES, N. E. V. B. Anatomia das artérias coronárias. Revista de Medicina de São Paulo, v. 72, p. 21-24, 1994.

MOURA JUNIOR, P. C.; VIEIRA, T. H. M. V.; VIEIRA, S. R. C.; PINTO NETO, J. L.; LEÃO, C. E. S.; LOPES, A. K. M. S.; RUIZ, C. R.; WAFAE, G. C.; SILVA, N. C.; WAFAE, N. Estudo anatômico das artérias coronárias em caprinos. Pesquisa Veterinária Brasileira, v. 29, n. 4, p. 358-362, 2009. doi: 10.1590/S0100-736X2009000400014.

MOURA JUNIOR, P. C.; VIEIRA, T. H. M.; VIEIRA, S. R. C.; SOBREIRO, D.; RUIZ, C. R.; WAFAE, G. C.; SILVA, N. C.; WAFAE, N. Estudo anatômico das artérias coronárias de suínos Landrace. Pesquisa Veterinária Brasileira, v. 28, n. 2, p. 103-107, 2008. doi: 10.1590/S0100-736X2008000200002.

NETTER, F. H. Atlas de anatomia humana. 4. ed. Rio de Janeiro: Elsevier, 2008. 638 p.

NOWAK, R. M. (ed.). Walker's mammals of the world. 6. ed. Baltimore: The Johns Hopkins University Press, 1999. 2 v. 2015 p.

PAULA, W. Estudo estatístico sobre irrigação coronariana no coração humano em brancos e negros. Folha Clínica Biológica, v. 1, n. 1, p. 18-40, 1972.

SAHNI, D.; KAUR, G. D.; JIT, H.; JIT, I. Anatomy and distribution of coronary arteries in pig in comparison with man. The Indian Journal of Medical Research, v. 127, n. 6, p. 564-570, 2008.

SCHANAIDER, A.; SILVA, P. C. Uso de animais em cirurgia experimental. Acta Cirurgica Brasileira, v. 19, n. 4, p. 441-447, 2004 doi: 10.1590/S010286502004000400014 .

SCHLESINGER, M. J. Significant variations in the anatomic pattern of the coronary vessels. Blood, Heart and Circulation, v. 13, p. 61-72, 1940.

VASKO, J. S.; GUTELIUS, J.; SABISTON JUNIOR, D. C. A study of predominance of human coronary arteries determined by arteriographic and perfusion technics. The American Journal of Cardiology, v. 8, n. 3, p. 379384, 1961. doi: 10.1016/0002-9149(61)90157-6. 
VIEIRA, T. H. M.; MOURA JUNIOR, P. C.; VIEIRA, S. $\quad$ European Journal of Anatomy, v. 7, p. 29-41, 2003. R. C.; MOURA P. R.; SILVA, N. C.; WAFAE, G. C.; RUIZ, Supplement.

C. R.; WAFAE, E. Anatomical indicators of dominance between the coronary arteries in swine. Morphologie, v. 92, n. 296, p. 3-6, 2008. doi: 10.1016/j.morpho.2008.04.005.

VILALLONGA, J. R. Anatomical variations of the coronary arteries: I. the most frequent variations.

WEAVER, M. E.; PANTELY, G. A.; BRISTON, J. D.; LADLEY, H. D. A quantitative study of the anatomy and distribution of coronary arteries in swine in comparison with other animals and man. Cardiovascular Research, v. 20 , n. 12 , p. $907-917,1986$. doi: 10.1093/cvr/20.12.907. 